\title{
TESTING OF THE NUTRITIVE VALUE OF WINGED BEAN PSOPHOCARPUS TETRAGONOLOBUS (L.) DC OIL FOR BROILERS
}

\author{
B. RITTICH ${ }^{1}$, Z. GASNÁREK ${ }^{2}$ and F. POSPÍS̆IL ${ }^{3}$ \\ University of Veterinary and Pharmaceutical Sciences, $61242 \mathrm{Brno}^{1}$ \\ Research Institute of Animal Nutrition, 69123 Pohořelice $^{2}$ \\ University of Agriculture Brno, 69114 Lednice na Moravě ${ }^{3}$
}

Received October 12, 1992

\begin{abstract}
Rittich, B., Z. Gasnárek, F. Pospíšil: Testing of the Nutritive Value of Winged Bean Psophocarpus tetragonolobus (L.) DC Oil for Broilers. Acta vet. Brno, 62, 1993: $133-138$.

In the oil of seeds of the tropical legume Psophocarpus tetragonolobus (L.) DC (winged bean) of Vietnamese provenance the content of higher fatty acids was determined. Compared with soybean and peanut oils, winged bean oil contains more acids with a long carbon chain $\mathrm{C}_{20}-\mathrm{C}_{24}$. In order to verify the nutritive values of winged bean oil, an experiment on broilers was carried out. An addition of $50 \mathrm{~g} / \mathrm{kg}$ oil into the BR-2 feed mixture enhanced the body mass gains significantly $(P<0.05)$ in comparison with the control. The effect of winged bean oil on weight gain however, was not so significant as of fodder fat $(P<0.01)$. The differences between the above-mentioned treatments were still statistically non significant. Furthermore, the most convenient conditions of extraction of the oil from seeds, the solvent/cake ratio and the extraction time were verified.
\end{abstract}

Psophocarpus tetragonolobus oil, extraction, fatty acids, nutritional value, broilers

The legume Psophocarpus tetragonolobus (L.) DC comes from the tropical regions of Asia where it is cultivated to a limited extent. Only the seeds, immature pods and tubers, in particular, are used for human nutrition. The seeds contain a great amount of nitrogenous substances (30 to 40\%) - (Okezie and Martin 1980; Ekpenyong and Borchers 1980; Higuchi et al. 1982; Homma et al. 1983; Ibuki et al. 1983; Rittich et al. 1989).

Meal from the seed of the legume is used especially as the initial raw material for the foodprocessing industry. In their study, Kanty and Erdman (1984) gave a detailed survey on this issue. There is much less information available about the use of psophocarpus oil. Bodger et al. (1982) gave the most exhausting information about the properties of winged bean oil obtained from 11 cultivars grown in Thailand. Fernando and Bean (1985) studied the content of behenic acid in 12 different psophocarpus cultivars. Winged bean oil, compared with soybean and peanut oils, contains a higher amount of fatty acids of the $\mathrm{C}_{22}-\mathrm{C}_{24}$ series, particularly of behenic acid $\left(\mathrm{C}_{22}:_{0}\right)$. In spite of the fact that the above mentioned acids are less digestible, it had not been proved that winged bean oil was toxic (Kanta and Erdman 1984).

The aim of the present study was to determine the content of higher fatty acids in the oil of the seeds of the legume Psophocarpus tetragonolobus (L.) DC of Vietnamese provenance and to study how additions of this oil to feed rations affect the growth of broilers. The method of oil extraction from the above legume was verified.

\section{Materials and Methods}

The seeds of the legume Psophocarpus tetragonolobus (L.) DC of Vietnamese provenance (not indicating the cultivar) were used, and were provided by the workers of the Institute for Tropical and Subtropical Agriculture of the University of Agriculture in Prague. The cake from the seeds 
was extracted with n-hexane (Tukový průmysl /Fats Industry/, Ústí nad Labem) in a charged heated extracting apparatus. The cake was separated from the solvent by filtration on a vacuum filter. The solvent was removed from the oil on a rotating vacuum evaporator. The seeds were processed in Lachema Brno. Due to the fact that the method ef extraction of winged bean oil was the object of investigations, this method has been described in "Results and Discussion".

The determination of methyl esters of the higher fatty acids in a petrolether extract from seeds was carried out according to the ČNN (Czechoslovak Standard) 560059 (1972) on a Chrom 4 gas chromatograph (Laboratorní prístroje, Prague) thanks to the company laboratory of the Research Institute of the Tukový prủmysl in Usti nad Labem. They were quantified using internal normalization. The analyses of nutrients and macro-elements in the feeds and feed mixtures were carried out according to the CSN 467013 (1978) and CSN 467092 (1986). The fibre content was determined using the Fibertec (Tecator, Sweden) apparatus as modified by Rittich and Žaludová (1985). The content of $\mathrm{N}$-substances was determined on the apparatus Kjel-Foss Automatic, model 16210 (Kjel-Foss, Denmark).

\section{Experiments with poultry}

The objective was to study the effect of winged bean oil in the BR-2 feed mixture on some parameters of performance of broilers. The experiment was carried out with broilers of the Ross hybrid and lasted for 7 weeks. The chicks were kept in cages and were given loose mixtures. Feed and drinking water was available ad libitum. Up to 3 weeks of age all the chicks were fed the same BR-1 mixture. Then they were fed the experimental BR-2 mixture. Table 1 gives the composition of the feed mixtures, content of nutrients and macro-elements. Lard was used as fodder fat. The experiment was arranged in three batches and two repetitions. There were 20 cockerels in each batch.

The design of the experiment was as follows:

$\begin{aligned} \text { Batch } & \text { Group } \\ \text { I } & \text { control } \\ \text { II } & \text { experimental with } 50 \mathrm{~g} \text { of feed fat } / \mathrm{kg} \text { of mixture } \\ \text { III } & \text { experimental with } 50 \mathrm{~g} \text { of winged bean oil } / \mathrm{kg} \text { of mixture }\end{aligned}$

The faecal samples for consequential determination of higher fatty acids were taken for 5 days in the 7th week of the experiment. The results of the experiment were evaluated using the variance analysis according to Snedecor and Cochran (1969).

\section{Results and Discussion}

Due to the fact that the winged bean seeds contain $15-20 \%$ of oil, extraction was chosen as the method for obtaining it, as recommended in literature (Rodger et al. 1982). First of all, the most convenient conditions for extraction were verified in the laboratory, i.e. the solvent/cake ratio and the duration of extraction at $50^{\circ} \mathrm{C}$. The results are given in Table 2 . The lowest content of oil in the extracted cake was found during two-stage extraction, the solvent/cake ratio being 5:1 and duration of extraction 30 minutes.

Based on the laboratory experiment, two-stage extraction was used for the processing of $62.3 \mathrm{~kg}$ of winged bean cake, the solvent/cake ratio being $5: 1$ and duration of extraction in each stage 30 minutes at $50^{\circ} \mathrm{C}$. A total of $8.5 \mathrm{~kg}$ of oil was obtained, i.e. the yield from the extraction was $80.2 \%$. In the cake $1.2 \mathrm{~kg}$ of oil remained unextracted, i. e. $11.2 \%$ of the total amount. Losses reached $0.9 \mathrm{~kg}$ of oil (i.e. $8.6 \%$ ). It is assumed that higher yields can be reached if countercurrent extraction is used.

The content of higher fatty acids was found to be higher in the extracted oil, as shown in Table 3 . Compared with soybean and peanut oils, winged bean oil contains more acids with a long carbon chain $\mathrm{C}_{20}-\mathrm{C}_{24}$. The content of these acids corresponded with data given in literature (Ekpenyong and Borchers 1980; Bodger et al. 1982; Fernando and Bean 1985). The content of ligno- 
Table 1

The composition and content of nutrients in experimental feed mixtures $(\mathrm{g} / \mathrm{kg})$

\begin{tabular}{|c|c|c|c|c|}
\hline \multirow{3}{*}{ Components } & \multicolumn{4}{|c|}{ Mixture } \\
\hline & \multirow{2}{*}{ BR - 1} & \multicolumn{3}{|c|}{ BR - 2} \\
\hline & & I & II & III \\
\hline $\begin{array}{l}\text { Maize } \\
\text { Wheat } \\
\text { Soybean extr. meal } \\
\text { Fish meal } \\
\text { Meat-bone meal } \\
\text { Ethanol yeast } \\
\text { Feed fat } \\
\text { Winged bean oil } \\
\text { MKP2-SP } \\
\text { DB BR-1 } \\
\text { DB BR-2 }\end{array}$ & $\begin{array}{r}450 \\
190 \\
250 \\
30 \\
10 \\
10 \\
= \\
\overline{40} \\
10 \\
-\end{array}$ & $\begin{array}{r}530 \\
130 \\
250 \\
10 \\
20 \\
10 \\
= \\
\overline{40} \\
\overline{10}\end{array}$ & $\begin{array}{r}480 \\
130 \\
250 \\
10 \\
20 \\
10 \\
50 \\
\frac{40}{10}\end{array}$ & $\begin{array}{r}480 \\
130 \\
250 \\
10 \\
20 \\
10 \\
-50 \\
40 \\
\frac{10}{10}\end{array}$ \\
\hline $\begin{array}{l}\mathrm{N} \times 6.25 \\
\text { Fat } \\
\text { Fibre } \\
\text { Ash substances } \\
\mathrm{Na} \\
\mathrm{K} \\
\mathrm{Ca} \\
\mathrm{P} \\
\mathrm{Mg}\end{array}$ & $\begin{array}{r}251.0 \\
44.3 \\
38.9 \\
94.8 \\
2.3 \\
6.7 \\
18.0 \\
10.1 \\
3.1\end{array}$ & $\begin{array}{r}247.1 \\
32.8 \\
35.5 \\
61.0 \\
1.4 \\
7.6 \\
11.9 \\
8.1 \\
2.8\end{array}$ & $\begin{array}{r}235.2 \\
98.3 \\
35.4 \\
86.5 \\
2.1 \\
7.0 \\
17.3 \\
9.6 \\
2.9\end{array}$ & $\begin{array}{r}223.0 \\
85.4 \\
40.2 \\
86.6 \\
1.9 \\
7.0 \\
17.4 \\
9.8 \\
3.0\end{array}$ \\
\hline
\end{tabular}

Table 2

The effect of experimental conditions on the yields of extraction of oil from the legume Psophocarpus tetragonolobus (L.) DC

\begin{tabular}{|c|c|c|c|c|c|}
\hline \multicolumn{3}{|c|}{$\begin{array}{c}\text { Stage of extraction } \\
\text { solvent/meal }(\mathrm{ml} / \mathrm{g})\end{array}$} & \multicolumn{3}{|c|}{$\begin{array}{l}\text { Duration of extraction (min.) } \\
\text { content of oil in extracted meal } \\
(\mathrm{g} / \mathrm{kg})\end{array}$} \\
\hline & 0 & 15 & 20 & 25 & 30 \\
\hline $\begin{array}{l}I^{\mathrm{a}} \\
2.5: 1.0 \\
5.0: 1.0 \\
\text { II } \\
2.5: 1.0 \\
5.0: 1.0\end{array}$ & $\begin{array}{r}171.6 \\
171.6 \\
40.2 \\
34.8 \\
40.2 \\
34.8\end{array}$ & $\begin{array}{r}56.3 \\
43.9 \\
- \\
= \\
=\end{array}$ & $\begin{array}{l}51.9 \\
33.0 \\
= \\
= \\
=\end{array}$ & $\begin{array}{c}44.1 \\
34.3 \\
= \\
= \\
=\end{array}$ & $\begin{array}{l}40.2 \\
34.8 \\
27.9 \\
25.9 \\
21.1 \\
22.0\end{array}$ \\
\hline
\end{tabular}

$\mathrm{a}-20.0 \mathrm{~g}$ of meal was used for extraction

Table 3

Content of higher fatty acids in oil from seeds of the legume Psophocarpus tetragonolobus (L.) DC

\begin{tabular}{|c|c|c|c|c|c|c|c|c|c|c|c|c|c|}
\hline \multirow{2}{*}{ Material } & \multicolumn{13}{|c|}{ Acid (internal normalization - \%) } \\
\hline & $14: 0$ & $16: 0$ & $16: 1$ & $18: 0$ & $18: 1$ & $18: 2$ & $18: 3$ & $20: 0$ & $20: 1$ & $22: 0$ & 22: 1 & $24: 0$ & $\mathbf{P}$ \\
\hline $\begin{array}{l}\text { Winged bean } \\
\text { oil } \\
\qquad \begin{array}{l}\text { a } \\
\text { b } \\
\text { c }\end{array}\end{array}$ & $\begin{array}{l}\overline{0.2} \\
0.1 \\
0.1\end{array}$ & $\begin{array}{r}8.4 \\
9.1 \\
10.4 \\
8.8\end{array}$ & $\begin{array}{l}0.3 \\
0.4 \\
0.6 \\
0.4\end{array}$ & $\begin{array}{l}4.7 \\
5.4 \\
4.3 \\
5.3\end{array}$ & $\begin{array}{l}35.8 \\
41.0 \\
33.7 \\
36.0\end{array}$ & $\begin{array}{l}29.6 \\
29.5 \\
29.0 \\
24.8\end{array}$ & $\begin{array}{l}1.1 \\
1.9 \\
2.1 \\
1.0\end{array}$ & $\begin{array}{l}1.6 \\
2.0 \\
1.1 \\
1.4\end{array}$ & $\begin{array}{l}2.9 \\
2.2 \\
3.1 \\
3.9\end{array}$ & $\begin{array}{r}12.4 \\
7.3 \\
11.3 \\
14.9\end{array}$ & $\frac{1.1}{-}$ & $\begin{array}{l}2.4 \\
1.0 \\
2.5 \\
3.4\end{array}$ & $\begin{array}{l}2.42 \\
3.00 \\
2.27 \\
1.95\end{array}$ \\
\hline Soybean oil $_{\mathrm{d}}$ & 0.1 & 11.0 & 0.1 & 4.0 & 25.0 & 50.0 & 8.0 & 0.4 & - & 0.3 & - & - & 4.92 \\
\hline Peanut oil $d$ & 0.4 & 10.0 & 1.7 & 4.0 & 61.0 & 18.0 & - & 0.9 & 1.1 & 2.5 & - & 1.0 & 4.49 \\
\hline
\end{tabular}

a Ekpenyong and Borchers (1980), b - Higuchi et al. (1982), c - Homma et al. (1983), d - Hilditch and Williams (1964)

p - unsaturated acids : saturated acids 
ceric acid $\left(\mathrm{C}_{24}:{ }_{0}\right)$ was somewhat higher (but for different varieties) than was stated by Ekpenyong and Borchers (1980) and Fernando and Bean (1985).

Due to the high content of fatty acids of the $\mathrm{C}_{20}-\mathrm{C}_{24}$ series, particularly behenic acid $\left(\mathrm{C}_{22}:{ }_{0}\right)$, the oil from winged bean seeds is unsuitable for direct food consumption. Olein and stearin fractions were obtained from technological processing of oil (cleavage into fatty acids and glycerin) as they can be further used for food and for technical purposes (List 1987).

The experiment with broilers was carried out in order to verify the nutritional value of winged bean oil. An addition of $50 \mathrm{~g}$ of oil $/ \mathrm{kg}$ of the feed mixture BR-2 was found to increase significantly $(P<0.05)$ their weight gain. The effect of winged bean oil was not as significant as that of fodder fat $(P<0.01)$, but the differences between batches I and II were non significant, see Table 4. Since the broilers were not kept individually, feed consumption (kg per $\mathrm{kg}$ weight gain) could not be statistically evaluated. The results given in Table 4 must therefore be understood as a certain trend that is in accordance with the results of the increments obtained. It is interesting that no expressive accumulation of acids of the $\mathrm{C}_{20}-\mathrm{C}_{24}$ series (with the exception of lignoceric acid $\mathrm{C}_{24}: 0$ ) was observed in the faeces of the broilers (Table 5). This fact only proves that these acids had been partially absorbed in the digestive tract of the broilers. The high content of behenic acid $\left(\mathrm{C}_{22}:{ }_{0}\right)$ in the faeces corresponds to the content of this acid in the oil. However, in order to obtain more accurate data about the accumulation of higher fatty acids in the faeces of the broilers, a total balance of substances had to be carried out. It can be said that the lower weight gain in batch III, as compared with batch II, could be due to the lower content of $\mathrm{N} \times 6.25$ in the mixture.

Table 4

Basic parameters of performance of experimental chicks

\begin{tabular}{|c|c|c|c|c|c|c|}
\hline \multirow[b]{3}{*}{ Period } & \multicolumn{6}{|c|}{ Groups/parameter } \\
\hline & \multicolumn{2}{|c|}{ I } & \multicolumn{2}{|c|}{ II } & \multicolumn{2}{|c|}{ III } \\
\hline & $\begin{array}{c}\text { weight gain } \\
(\mathrm{g})\end{array}$ & $\begin{array}{c}\text { feed } \\
\text { consumption } \\
(\mathbf{k g} / \mathbf{k g} \\
\text { weight gain) }\end{array}$ & $\begin{array}{l}\text { weight gain } \\
\text { (g) }\end{array}$ & $\begin{array}{c}\text { feed } \\
\text { consumption } \\
(\mathrm{kg} / \mathrm{kg} \\
\text { weight gain) }\end{array}$ & $\begin{array}{c}\text { weight gain } \\
\text { (g) }\end{array}$ & $\begin{array}{c}\text { feed } \\
\text { consumption } \\
(\mathrm{kg} / \mathrm{kg} \\
\text { weight gain) }\end{array}$ \\
\hline $\begin{array}{l}\text { 1st }-3 \text { rd week } \\
\text { 4th }-5 \text { th week } \\
\text { 6th }-7 \text { th week } \\
\text { 4th }-7 \text { th week }\end{array}$ & $\begin{array}{c}470 \\
774 \mathrm{a} \\
914 \mathrm{a} \\
1678 \mathrm{~A}, \mathrm{a}\end{array}$ & $\begin{array}{l}1.95 \\
2.03 \\
2.52 \\
2.28\end{array}$ & $\begin{array}{ll} & 501 \\
& 887 \mathrm{~b} \\
1 & 036 \mathrm{~b} \\
1 & 919 \mathrm{~B}\end{array}$ & $\begin{array}{l}1.83 \\
2.00 \\
2.32 \\
2.17\end{array}$ & $\begin{array}{r}475 \\
842 \mathrm{a} \\
980 \mathrm{a} \\
1839 \mathrm{~b}\end{array}$ & $\begin{array}{l}1.85 \\
2.01 \\
2.52 \\
2.26\end{array}$ \\
\hline
\end{tabular}

a, b - statistically significant difference for $P<0.05$

A, B - statistically highly significant difference for $\mathrm{P}<0.01$

The means indicated with the same letters are the same

Table 5

Content of higher fatty acids in the faeces of broiler cocks

\begin{tabular}{|c|c|c|c|c|c|c|c|c|c|c|}
\hline \multirow{2}{*}{ Group } & \multicolumn{10}{|c|}{ Acid (internal normalization - \%) } \\
\hline & $\mathrm{C}_{16: 0}$ & $\mathrm{C}_{18: 0}$ & $\mathrm{C}_{18: 1}$ & $\mathrm{C}_{18: 2}$ & $\mathrm{C}_{18: 3}$ & $\mathrm{C}_{20: 0}$ & $\mathrm{C}_{20: 1}$ & $\mathrm{C}_{22: 0}$ & $\mathrm{C}_{22: 1}$ & $\mathrm{C}_{24: 0}$ \\
\hline II & $\begin{array}{l}10.1 \\
11.6 \\
14.0\end{array}$ & $\begin{array}{l}3.1 \\
6.7 \\
6.5\end{array}$ & $\begin{array}{l}27.1 \\
28.2 \\
21.8\end{array}$ & $\begin{array}{l}51.9 \\
42.8 \\
35.1\end{array}$ & $\begin{array}{l}1.8 \\
1.5 \\
1.4\end{array}$ & $\begin{array}{l}0.6 \\
0.7 \\
1.7\end{array}$ & $\begin{array}{l}0.8 \\
0.7 \\
1.6\end{array}$ & $\begin{array}{r}2.3 \\
0.4 \\
13.0\end{array}$ & $\begin{array}{l}0.4 \\
0.1 \\
1.1\end{array}$ & $\begin{array}{l}0.6 \\
0.4 \\
3.2\end{array}$ \\
\hline Winged bean oil & 8.4 & 4.7 & 35.8 & 29.6 & 1.1 & 1.6 & 2.9 & 12.4 & 1.1 & 2.4 \\
\hline
\end{tabular}


In conclusion it should be stated that winged bean oil is a valuable raw material for the fats and feed industry. In order to spread its usability, it will be necessary to devote attention to the breeding of cultivars which have a low level of fatty acids of the $\mathrm{C}_{20}-\mathrm{C}_{24}$ series in the oil.

\section{Experimentální ověření nutriční hodnoty oleje z luskoviny Psophocarpus tetragonolobus (L.) DC u brojlerů}

V oleji ze semen luskoviny Psophocarpus tetragonolobus (L.) DC vietnamské provenience byl stanoven obsah vyšších mastných kyselin. Oproti sójovému a podzemnicovému oleji má psofokarpový olej vyšší zastoupení kyselin s dlouhým uhlíkovým řetězcem $\mathrm{C}_{20}-\mathrm{C}_{24}$. $\mathrm{Za}$ účelem ověření nutriční hodnoty psofokarpového oleje byl proveden pokus na brojlerech. Bylo zjištěno, že přídavek $50 \mathrm{~g} / \mathrm{kg}$ oleje do krmné směsi $\mathrm{BR}-2$ významně zvýšil $(P<0.05)$ jeijch prírůstek. Vliv psofokarpového oleje nebyl ale tak výrazný jako u krmného tuku $(P<0,01)$. Rozdíly mezi uvedenými zásahy byly ale statisticky nevýznamné. Dále byly ověřovány nejvhodnější podmínky extrakce oleje ze semen - poměr rozpouštědlo/ /šrot a doba extrakce.

\section{Экспериментальная оценка питательной ценности масла стручкового растения Psophocarpus tetragonolobus (L.) DC у бройлеров}

В масле из семян стручкобого растения Psophocarpus tetragonolobus (L.) DC вьетнамского происхождения определялось содержание высших жирных кислот. По сравнению с соевым и арахидным маслами, псофокарповое масло показывает более высокое содеержание кислот с длинной углеродной цепью $\mathrm{C}_{20}-\mathrm{C}_{24}$. Для удостоверения питательной ценности псофокарпового масла осуществился опыт на бройлерах. Было установлено, что добавление $50 \mathrm{r} / \mathrm{kr}$ масла в кормовую смесь BR-2 значительно повысило их прирост $(\mathrm{P}<0,05)$. Но влияние псофорарпового масла не было так выразительным как у кормового жира $(\mathrm{P}<0,01)$. Однако, различия между приведенными исследованиями были статистически незначительными. Далее проверялись самые удобные условия для экстракции масла из семян - отношение растворителt/шрот - и время экстракции.

\section{References}

BODGER, D. - DAVIS, J. B. - FARMERY, D. - HAMMONDS, T. W. - HARPER, A. J.HARRIS, R. V. - HEBB, L. - MacFERLANE, N. - SHANKS, P. - SOUTHWELL, K.: An Investigation of the Extraction, Refining and Composition of Oil from Winged Bean [Psophocarpus tetragonolobus (L.) DC], JAOCS, 59, 1982: 523-530

EKPENYONG, T. E. - BORCHERS, R. L.: The Fatty Composition of the Oil of the Winged Bean [Psophocarpus tetragonolobus (L.)] Seeds, JAOCS, 57, 1980: 147-149

EKPENYONG, T. E. - BORCHERS, R. L.: Amino acid profile of the seed and other parts of the winged bean, Food chem., 9, 1982: 175-182

FERNANDO, T.-BEAN, G.: Variation of the Anti-nutritional Behenic Acid Content Among the Cultivars of Winged Bean (Psophocarpus tetragonolobus (L.) DC), Food chemistry, 18, 1985: $265-269$

HILDITCH, T. P.- WILLIAMS, P. N.: The Chemical Composition of Natural Fats, 4th ed. London, Chapman and Hall 1964 
HIGUCHI, M. - TERAO, J. - IWAI, K.: Gas Chromatography-Mass Spectrophotometric Determination of Fatty Acids in Seed Oil of Winged Bean (Psophocarpus tetragonolobus (L.) DC), J. Nutr. Sci. Vitaminol., 28, 1982: 511-518

HOMA, S. - OMACHI, M. - TAMURA, A. - ISHAK, E. - FUJIMAKI, M.: Lipid composition of Winged Bean (Psophocarpus tetragonolobus), J. Nutr. Sci. Vitaminol., 29, 1983: 375380

IBUKI, F. - KOTARU, M.-KAN, K. K. - IKEUCHI, T. - KANAMORI, M.: Chemical Composition of Winged Bean (Psophocarpus tetragonolobus) Varieties, J. Nutr. Sci. Vitaminol., 29, 1983: $621-629$

KANTA, S. S. - ERDMAN, J. W.: The Winged Bean as an Oil and Protein Source: A Review, JAOCS, 61, 1984: 515-525

LIST, J.: Tukový prủmysl - Výzkumný ústav, Ústí nad Labem, soukromé sdělení (personal communication), 1987

OKEZIE, B. O.-MARTIN, F. W.: Chemical composition of dry seeds and fresh leaves of winged bean varieties grown in the U.S. and Puert Rico, J. Food Sci., 45, 1980: 1045-1051

RITTICH, B.-ŽALUDOVÁ, R.: Modifikace Henneberg-Stohmanovy metody stanovení vlákniny - vliv způsobu filtrace na obsah stanovené vlákniny, Živočiš. Výr., 30, 1985: 289-294

RITTICH, B. - GASNÁRKOVÁ, B. - MUSIL, V.: Chemické složení semen luskoviny Psophocarpus tetragonolobus (L.) DC vietnamské provenience, Živočiš. Výr., 34, 1989: 569-576

SNEDECOR, G. W. - COCHRAN, W. G.: Statistical Methods, 6th ed. The Iowa State University Press, Ames, Iowa, 1969: 593p.

ČSN 56 0059: Stanovení kyseliny linolové a linolenové, Praha, 1972

CSN 46 7013: Metody zkoušení krmných směsí, Praha, 1978

ČSN 46 7092: Metody zkoušení krmiv, Praha, 1986 